\title{
РЕКОМЕНДАЦІЇ ЩОДО ВИКЛАДАННЯ МЕТОДИКИ ВИЗНАЧЕННЯ РІВНЯ ВОСННОЇ БЕЗПЕКИ ДЛЯ СЛУХАЧІВ ОПЕРАТИВНО-ТАКТИЧНОГО РІВНЯ НАВЧАННЯ
}

\begin{abstract}
Відомо, щзо воєнна безпека досягається комплексним використанням політичного, воєнного, економічного, науково-технологічного, демографічного, ресурсного, інформаційного, морально-психологічного потенціалів країни і спрямована, насамперед, на зниження рівня воєнної небезпеки в будь-яких умовах.

Однією з важливих у ицьому плані була і залишається проблема вироблення і реалізації виваженої воєнної політики, яка має враховувати геополітичну ситуацію в Центральній та Східній Європі, базуватися на реальних економічних можливостях України, відповідати вимогам збереження ї̈ суверенітету й територіальної иілісності, ураховувати не лише свої національні інтереси, а й інтереси сусідніх держав, їх воєнний потенціал, можливість мирного розвитку.
\end{abstract}

Виконуючи иільову настанову навчальної дисципліни “Основи воєнної безпеки держави” стосовно необхідності формування у слухачів оперативно-тактичного рівня практичних навичок і умінь, які необхідні під час підготовки і проведення заходів щцодо забезпечення воєнної безпеки держави, викладачі кафедри викладачі кафедри СНБО неодноразово відмічають певні труднощі в оволодінні навчальним матеріалом.

Аналіз показав, що переважною більшістю слухачів найбільш важко сприймаються питання, пов'язані з визначенням рівня воєнної безпеки. На погляд багатьох фахівиів кафедри, ие обумовлено не лише тим, щцо багато хто з слухачів вперше у своєї діяльності стикнулися із зазначеними питаннями, а й певною складністю формулювань, які характеризують поняття “воєнна загроза", “воєнна небезпека” $і$ особливо їх зв'язком між собою та відповідним визначенням рівнів воєнної безпеки та воєнної небезпеки.

У статті проаналізовано проблеми засвоєння слухачами оперативно-тактичного рівня навчання навчального матеріалу з питань воєнної безпеки та иляхи їх вирішення. Зроблено висновок про те, що користуючись запропонованими визначеннями та показниками слухачам можна протягом декількох навчальних годин провести аналіз стану воєнно-політичних відносин України із усіма сусідніми країнами, оцінити ступінь небезпек, характер воєнних загроз, передбачити можливі сценарії розвитку подій, обрахувати інтегральний рівень впливу загроз на національні інтереси у воєнної сфері визначити рівень воєнної безпеки і відповідно запропонувати заходи щэодо його підвищення, тобто виробляти вміння працювати в ролі посадової особи органу управління стратегічного рівня.

Ключові слова: воєнна безпека, рівень воєнної безпеки, воєнна небезпека.

Постановка проблеми. Однією 3 важливих питань воєнної безпеки держави була i залишається проблема вироблення i реалізації виваженої воєнної політики, яка має враховувати геополітичну ситуацію в Центральній та Східній Європі, базуватися на реальних економічних можливостях України, відповідати вимогам збереження їі суверенітету й територіальної цілісності, 
ураховувати не лише свої національні інтереси, а й інтереси сусідніх держав, їх воєнний потенціал, можливість мирного розвитку.

Виконуючи цільову настанову навчальної дисципліни “Основи воєнної безпеки держави" стосовно необхідності формування у слухачів оперативнотактичного рівня практичних навичок і умінь, які необхідні під час підготовки і проведення заходів щодо забезпечення воєнної безпеки держави, викладачі кафедри викладачі кафедри СНБО неодноразово відмічали певні труднощі в оволодінні навчальним матеріалом. Аналіз показав, що переважною більшістю слухачів найбільш важко сприймаються питання, пов'язані з визначенням рівня воєнної безпеки.

У статті наведено пропозиції щодо удосконалення методики проведення практичних занять з визначення рівня воєнної безпеки.

Аналіз останніх досліджень i публікацій. Розв'язання вказаної проблеми потребувало звернутись до праць визнаних фахівців в галузі національної безпеки України В. Горбуліна [1,2], О. Власюка [3], В. Ліпкана [4]. 3 огляду на складні реалії сьогодення практично в усіх країнах світу, зокрема $\mathrm{i}$ в Україні, політики, науковці, фахівці у сфері національної безпеки і оборони обговорюють можливі напрями підвищення міжнародної і національної безпеки у воєнній сфері. Пропонуються різні заходи політичної, військової, економічної та іншої спрямованості, реалізація яких дозволила б запобігти виникненню нових війн і воєнних конфліктів або їх припинення 3 найменшими втратами людських і матеріальних ресурсів. Кожна країна обирає свій шлях вирішення цього складного питання. Слухачі Національного університету оборони імені Івана Черняховського на практичних заняттях 3 дисципліни Основи воєнної безпеки держави повинні вчитися аналізувати стан воєнної безпеки і готувати обгрунтовані пропозиції щодо вибору шляхів захисту держави від збройної агресії.

Мета дослідити чинники і фактори, які впливають на труднощі із засвоєння навчального матеріалу, та на підставі їх аналізу визначити наукові рекомендації щодо удосконалення якості навчання.

Виклад основного матеріалу.

Сучасний стан Збройних Сил України та реалії XXI століття вимагають якісно нових підходів до підготовки офіцерського складу, створення умов для ефективної та якісної підготовки, перепідготовки та підвищення кваліфікації військових фахівців шляхом запровадження сучасних навчально-тренувальних систем і комплексів, технологізації та інформатизації військової освіти, застосування сучасних освітніх інновацій, які могли б забезпечувати не тільки виконання завдань реформування військової освіти, а й сприяти всебічному розвитку суб'єктів навчання та їх успішній самореалізації в соціальному та військово-професійному середовищі.

Міністром оборони України та Головним командувачем ЗС України неодноразово наголошувалося на внесенні корінних змін має у навчальний процес у ВВНЗ. При цьому зверталась увага не лише на необхідності врахування в процесі підготовки курсантів і слухачів досвіду проведення 
антитерористичної операції, операції об’єднаних сил, тобто зміни мають торкнутися не лише змісту, а і технологій навчання.

У ході проведення практичних занять із слухачами оперативнотактичного рівня навчання 3 визначення рівня воєнної безпеки держави неодноразово виникали випадки різних підходів до тлумачення таких термінів як воєнна загроза та воєнна небезпека, розуміння яких є ключовим на шляху до обгрунтування ступеня воєнної безпеки.

Аналіз керівних документів, напрацювань українських та іноземних фахівців показав, що єдиного тлумачення зазначених термінів немає.

Так у навчальному посібнику В.А. Ліпкана "Національна безпека України", зазначається: "Воєнна загроза - стан, що характеризується існуванням потенційної можливості застосування воєнної сили проти держави для досягнення політичних і інших цілей яким-небудь суб'єктом військовополітичних відносин. Відмінність воснної небезпеки полягає в тому, що вона указує не на потенційну можливість, а на намір, що реально позначився, одній із сторін застосувати військову силу. Військова небезпека є вищим ступенем напруженості, яка характеризується відкритим протистоянням сторін, їх намірами вирішити існуючі протиріччя військово-силовими методами. Воєнна загроза не обов'язково пов'язана 3 початком військових приготувань протилежної сторони. іiі джерела, як правило, приховані від поверхневого погляду людей”.'[4].

Водночас у словнику - довіднику за редакцією Г.П. Ситника "Глобальна та національна безпека" встановлюються терміни, які по іншому розкривають відзначені поняття: Воєнна загроза - вища форма прояву воєнної небезпеки, в умовах якої існує безпосередня ймовірність виникнення збройного конфлікту, воєнна небезпека - стан міждержавних і внутрішньодержавних відносин, при якому існує потенційна можливість виникнення збройного конфлікту”.[5].

У законі України Про національну безпеку України визначено: “воснна безпека - захищеність державного суверенітету, територіальної цілісності i демократичного конституційного ладу та інших життєве важливих національних інтересів від воснних загроз”.[6].

Водночас поняття “воснна загроза" у зазначеному законі не розкривається, визначено більш широке поняття “загрози національній безпеці України" - явища, тенденції і чинники, що унеможливлюють чи ускладнюють або можуть унеможливити чи ускладнити реалізацію національних інтересів та збереження національних цінностей України”.

Що стосується терміну “воснна загроза", то він згадується у Воєнній доктрині України (пункт 9),однак поряд 3 ним у зазначеному документі застосовуються ще два поняття, які можна вважати тотожними: “загроза застосування воснної сили" (пункт 4) та “загрози воснній безпеці України"(пункт 11), при цьому тлумачення розкривається лише одного з них, а саме "загроза застосування воснної сили", яке формулюється як наміри або дії однієї зі сторін воєнно-політичних відносин, які свідчать про готовність до застосування воєнної сили проти іншої сторони з метою досягнення власних цілей [7]. 
При цьому якщо порівняти зміст термінів “загрози національній безпеці Украӥни” та “загроза застосування воєнної сили” то вони суттєво відрізняються. Відрізняються не лише за сферами та масштабом, що цілком природно, а й за часом намірів, дій, явищ. Якщо у другому передбачається що загроза може завдати шкоди Україні лише у майбутньому (наміри або діï, які свідчать про готовність до застосування воєнної сили), то у першому термін загроза трактується так що це явища, тенденції і чинники, які не лише можуть унеможливити чи ускладнити реалізацію національних інтересів, а й вже відбулися (унеможливлюють чи ускладнюють).

Що стосується терміну "воєнна небезпека", то його визначення взагалі в діючих керівних документах не згадується. Останній раз в офіційному документі зазначений термін застосовувався у другій редакції Воєнній доктрині України 2004 року. Між тим розуміння значень цих термінів $є$ дуже важливим для визначення рівня воєнної безпеки.

У підручнику Основи воєнної безпеки держави, призначеного для підготовки слухачів оперативно-тактичного рівня Національного університету оборони України імені Івана Черняховського видання 2017 року “воснна небезпека" характеризує потенційну можливість будь-якої держави (коаліції держав) або військових (озброєних) формувань щодо застосування військової сили для вирішення політичних, економічних, територіальних, етнічних, релігійних та інших протиріч [8].

Тобто за змістом це визначення “воснна небезпека” (потенційна можливість щодо застосування військової сили) дуже схоже із терміном “загроза застосування воснної сили” (наміри або дії про готовність до застосування воєнної сили).

Це як раз і викликає труднощі у слухачів щодо класифікації тих чи інших подій навколо України, які можна характеризувати як такі, що знижують іiі рівень воєнної безпеки.

Насправді поняття “загроза" близьке за змістом до поняття "небезпека", причому вони настільки взаємопов'язані, що навіть C.I. Ожегов допускає в певному сенсі тавтологію, визначаючи загрозу через небезпеку i навпаки (“загроза є можлива небезпека", а “небезпека $\epsilon$, можливість, загроза чогонебудь дуже поганого, якого-небудь нещастя”). Строго окреслити параметри кожного $з$ цих понять досить складно. Тому часто доводиться стикатися 3 такими подвійними формулюваннями, як “загрозлива небезпека", “небезпечна загроза" і т.п. [9].

Наприклад у Воєнній доктрині України у пункті 30 підкреслюється: “найвищий ступінь небезпеки має загроза державному суверенітету та територіальній цілісності України. Головною такою загрозою $є$ ймовірність великомасштабної збройної агресії Російської Федерації проти України".

Тобто в принципі можна припустити, що разом це єдиний процес зростання напруженості у відносинах між державами (коаліціями держав), що може привести до застосування воєнної сили, у якому воєнна небезпека поступово перетворюється у воєнну загрозу. 
Автор статті пропонує у якості показників визначень воєнна загроза i воєнна небезпека 3 боку будь-якої країни обрати 2 головних критерію: перший - наміри і дії ії політичного керівництва щодо можливості застосування воєнної сили, другий - спроможності (бойовий потенціал) зазначеної країни.

Виникає питання: чому автор крім загальноприйнятих показників (наміри, діï) вважають додати до характеристики значень воєнна загроза i воєнна небезпека спроможності (бойовий потенціал).

Відповідь очевидна. За визначенням “спроможність - це здатність збройних сил виконувати певні завдання (забезпечувати реалізацію визначених військових цілей) за певних умов обстановки, ресурсного забезпечення та відповідно до встановлених стандартів" [10].

При цьому спроможності класифікуються як необхідні, наявні та критичні. Природно, що наміри політичного керівництва стосовно визначення тих чи інших воєнно-політичних цілей повинні базуватися на необхідних спроможностях, а інколи i критичних тобто абсолютно важливих для досягнення необхідного результату.

Таблиия 1

\begin{tabular}{|c|c|c|c|}
\hline \multicolumn{3}{|c|}{ Застосування воєнної сили } & \multirow[b]{2}{*}{ Характеристика } \\
\hline Наміри, дії & $\begin{array}{c}\text { Спроможності } \\
\text { (бойовий потенціал) }\end{array}$ & Можливість & \\
\hline $\mathrm{E}$ & $\mathrm{C}$ & Реальна & Воєнна загроза \\
\hline $\mathrm{Hi}$ & $E$ & \multirow{2}{*}{ Потенційна } & \multirow{3}{*}{ Воєнна небезпека } \\
\hline$E$ & $\mathrm{Hi}$ & & \\
\hline $\mathrm{Hi}$ & $\mathrm{Hi}$ & Уявна & \\
\hline
\end{tabular}

3 таблиці 1 можна побачити, що воєнна загроза - це крайня ступінь воєнної небезпеки, а воєнна небезпека - є можлива (потенційна) загроза, в обмежених масштабах.

В історії можна легко знайти приклади коли політичні лідери задля втілення у життя своїх амбіційних намірів здійснювали кардинальне збільшення чисельності збройних сил та набуття ними необхідних спроможностей.

Так, Гітлер з самого початку політичної кар'єри висловлював мету щодо поглинання Австрії: “Німецька Австрія обов'язково повинна повернутися у велику німецьку митрополію і при цьому не з господарчих міркувань. Сдина кров - єдина держава!” 3 приходом до влади у Німеччині у 1933 році він не приховував намірів щодо приєднання Австрії до Німеччини. Але на ті часи Німеччина внаслідок поразки у першій світовій війні і значних обмежень в галузі військового будівництва не мала достатньо могутніх збройних сил.

Масове військове виробництво і збільшення чисельності збройних сил, яке було розпочато з перших же років діяльності Гітлера на чолі країни дало йому підстави вже в 1938 році зробити зухвалу заяву австрійському канцлеру Шушнігу: "Варто тільки мені віддати наказ, і протягом однієї ночі весь ваш сміхотворний оборонний механізм розсиплеться нашматки". 
Армія Німеччини на той час, озброєна новітньою бойовою зброєю, добре підготовлена дозволяла диктатору не мати сумніву в успіху. Якщо в 1933 році рейхсвер складався зі ста тисяч чоловік, то в 1939 році вермахт вже налічував 12 армійських корпусів із 38 дивізій (3,2 мільйона чоловік).

Незабаром після цього відбулось поглинання Австрії, так званий “аншлюс".

Тобто на зазначеному прикладі яскраво проглядається динаміка перетворення воєнної небезпеки (спочатку поява намірів щодо поглинання Австрії) у воєнну загрозу (створення могутньої армії) і потім у практичне виконання намірів (здійснення збройного вторгнення в умовах фактичної відсутності військового опору).

Можна також згадати наміри Російської Федерації на початку 90-х років (заяви президента Бориса Єльцина, постанови російської Держдуми про російський статус Севастополя) добитися від України добровільного визнання Криму приналежним до Росії. У ті роки військовий потенціал Росії, після розпаду Радянського Союзу був достатньо слабким і тому зазначені питання так ї обмежувались заявами, деклараціями та виступами окремих діячів Костянтина Затуліна. Однак час йшов, збройні сили РФ нарощували м'язи, підвищували спроможності своєї військової бази в Криму і багатьом аналітикам було зрозуміло, що збройна агресія проти України на іiі півдні лише питання часу та вигідного моменту. Цей момент настав у 2014 році, коли російське керівництво скориставшись певною розгубленістю української влади у перші дні після перемоги революції гідності здійснило збройну агресію і порушило територіальну цілісність України шляхом тимчасової окупації Автономної Республіки Крим та міста Севастополя.

Якщо зазначені підходи використовувати при оцінці воєнно-політичних відносин України із конкретними країнами, наприклад країнами-сусідами, то можна отримати достатньо об'єктивну картину стосовно можливих перспектив воєнної безпеки держави відносно кожної окремої країни.

При цьому пропонуються такі виміри: воєнна небезпека від 0 до 0,5, воєнна загроза від 0,6 до 1 .

Особливу увагу слід звернути на зміст таблиці 2 . На відміну від варіанту (таблиця 3), в якому розглядається вплив загроз на національні інтереси у воєнній сфері пропонується інший, а саме вплив воєнних загроз та небезпек 3 боку суміжних країн на усі життєве важливі національні інтереси України, а не лише у воєнній сфері. Вважаю, що користуючись зазначеним варіантом слухачам набагато зручніше визначати вплив воєнних загроз, небезпек з боку сусідніх країн на долю України. Наприклад, очевидно, що загрози та небезпеки з боку Росії негативно впливають фактично на всі національні інтереси України і можуть оцінені слухачами від 0,6 до 0,9 . 
Таблиця 1

\begin{tabular}{|c|c|c|c|c|c|c|c|c|c|c|c|}
\hline \multirow[t]{2}{*}{$\begin{array}{l}\text { № } \\
\text { 3/ח }\end{array}$} & \multirow{2}{*}{$\begin{array}{c}\text { Національні } \\
\text { інтереси України }\end{array}$} & \multicolumn{7}{|c|}{$\begin{array}{l}\text { Воснні загрози, небезпеки з боку } \\
\text { сусідніх країн }\end{array}$} & \multirow{2}{*}{$\begin{array}{c}\text { Інтегральний } \\
\text { показник } \\
\text { впливу загроз } \\
\text { на } \\
\text { національний } \\
\text { інтерес } \\
\begin{array}{c}M=\frac{1}{N} \sum_{k=1}^{N} y_{k} \\
\end{array}\end{array}$} & \multirow{2}{*}{$\begin{array}{c}\text { Пріоритетніст } \\
\text { національних } \\
\text { інтересів } \\
\\
\\
\end{array}$} & \multirow{2}{*}{$\begin{array}{c}\text { Ступінь } \\
\text { реалізації } \\
\text { національних } \\
\text { інтересів } \\
R=1-M\end{array}$} \\
\hline & & $\theta$ & $\begin{array}{l}\text { 总 } \\
\text { 产 } \\
\text { 量 }\end{array}$ & 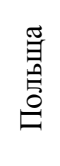 & 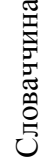 & $\begin{array}{l}\text { 焉 } \\
\text { 竞 } \\
\text { 号 }\end{array}$ & 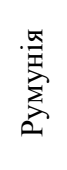 & 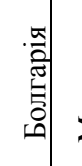 & & & \\
\hline I & $\begin{array}{l}\text { Державний } \\
\text { суверенітет і } \\
\text { територіальна } \\
\text { цілісність, } \\
\text { демократичний } \\
\text { конституційний } \\
\text { лад, } \\
\text { недопущення } \\
\text { втручання у } \\
\text { внутрішні справи } \\
\text { України } \\
\end{array}$ & & & & & & & & & & \\
\hline II & $\begin{array}{l}\text { Сталий розвиток } \\
\text { національної } \\
\text { економіки, } \\
\text { громадянського } \\
\text { суспільства і } \\
\text { держави }\end{array}$ & & & & & & & & & & \\
\hline III & $\begin{array}{l}\text { Інтеграція } \\
\text { України в } \\
\text { європейський } \\
\text { простір, } \\
\text { набуття } \\
\text { членства в СС } \\
\text { та НАТО }\end{array}$ & & & & & & & & & & \\
\hline IV & $\begin{array}{l}\text { Створення } \\
\text { безпечних умов } \\
\text { життєдіяльності } \\
\text { населення, } \\
\text { захисту і } \\
\text { відновлення } \\
\text { навколишнього } \\
\text { природного } \\
\text { середовища }\end{array}$ & & & & & & & & & & \\
\hline $\mathrm{V}$ & $\begin{array}{l}\text { Збереження і } \\
\text { розвиток } \\
\text { духовних і } \\
\text { культурних } \\
\text { цінностей } \\
\text { українського } \\
\text { суспільства }\end{array}$ & & & & & & & & & & \\
\hline
\end{tabular}




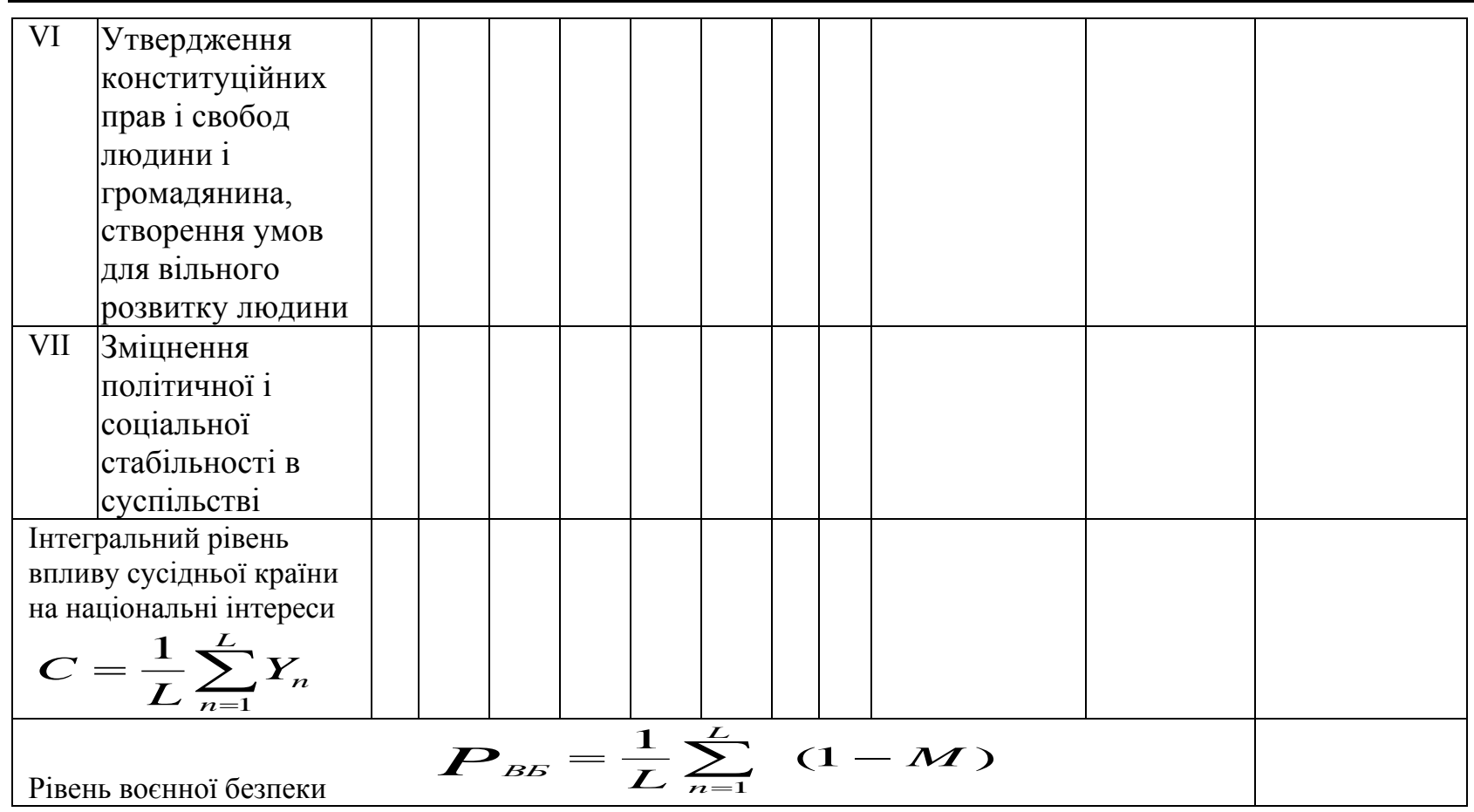

Розгляд же іншого варіанту, як показали практичні зайняття, інколи викликав певні непорозуміння. Наприклад, як можна оцінити вплив такої загрози як "мілітаризація Російською Федерацією тимчасово окупованої території шляхом формування нових військових з'єднань і частин, а також постачання бойовиків, ОВТ і МТЗ" або “присутність військового контингенту РФ у Придністровському регіоні Республіки Молдова" на такий національний інтерес у воєнній сфері як “розбудова сектору безпеки і оборони”. Звичайно на безпеку держави ці загрози впливають негативно, але разом з тим спонукають Україну набагато більше уваги приділяти розвитку оборонних можливостей, тобто розбудовувати сектор безпеки і оборони і фактично грають для його розвитку, як це ні парадоксально, позитивну роль. Саме це і викликало певні труднощі.

Користуючись зазначеними показниками за допомогою таблиць 1 та 2 на практичних заняттях із слухачами можна протягом декількох навчальних годин провести аналіз стану воєнно-політичних відносин України із усіма сусідніми країнами, оцінити ступінь небезпек, характер воєнних загроз, передбачити можливі сценарії розвитку подій, обрахувати інтегральний рівень впливу загроз на національні інтереси у воєнної сфері визначити рівень воєнної безпеки i відповідно запропонувати заходи щодо його підвищення тобто здійснити внесок у розробку науково обгрунтованих рішень 3 питань забезпечення воєнної безпеки держави. 
Таблиця 2

\begin{tabular}{|c|c|c|c|c|c|c|c|c|c|c|c|c|}
\hline \multirow{2}{*}{$\begin{array}{l}\text { № } \\
3 / \Pi\end{array}$} & \multirow[b]{2}{*}{$\begin{array}{l}\text { Національні } \\
\text { інтереси України у } \\
\text { воєнній сфері }\end{array}$} & \multicolumn{8}{|c|}{ Воєнні загрози } & \multirow[b]{2}{*}{\begin{tabular}{|l} 
Інтегральний \\
показник впливу \\
загроз на \\
національний \\
iнтерес \\
$M=\frac{1}{N} \sum_{k=1}^{N} y_{k}$
\end{tabular}} & \multirow{2}{*}{\begin{tabular}{|l|} 
Пріоритетніст \\
національних \\
iнтересів
\end{tabular}} & \multirow{2}{*}{$\begin{array}{c}\text { Ступінь } \\
\text { реалізації } \\
\text { національних } \\
\text { інтересів } \\
R=1-M\end{array}$} \\
\hline & & 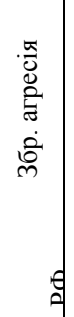 & 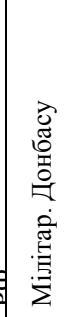 & 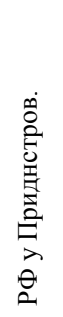 & 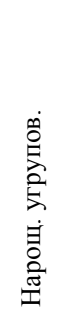 & 害 & 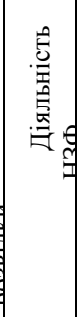 & 离: & 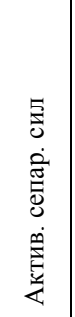 & & & \\
\hline I & \begin{tabular}{|l|} 
Стабілізація воєнно- \\
політичної \\
обстановки навколо \\
України і врегу- \\
лювання воєнних \\
конфліктів \\
\end{tabular} & & & & & & & & & & & \\
\hline II & $\begin{array}{l}\text { Розбудова сектору } \\
\text { безпеки і оборони }\end{array}$ & & & & & & & & & & & \\
\hline III & \begin{tabular}{|l|} 
Підтримка високої \\
боєздатності \\
військових \\
формувань \\
\end{tabular} & & & & & & & & & & & \\
\hline IV & $\begin{array}{l}\text { Забезпечення } \\
\text { мобілізаційних } \\
\text { ресурсів і резервів }\end{array}$ & & & & & & & & & & & \\
\hline $\mathrm{V}$ & $\begin{array}{l}\text { Розвиток } \\
\text { вітчизняної воєнної } \\
\text { науки }\end{array}$ & & & & & & & & & & & \\
\hline VI & $\begin{array}{l}\text { Створення цілісної } \\
\text { системи забезпечення } \\
\text { воєнної безпеки }\end{array}$ & & & & & & & & & & & \\
\hline VII & \begin{tabular}{|l} 
Впровадження \\
стандартів НАТО
\end{tabular} & & & & & & & & & & & \\
\hline $\begin{array}{l}\text { Інте } \\
\text { впль } \\
\text { наці } \\
\text { воєн } \\
\text { C }\end{array}$ & $\begin{array}{l}\text { гральний рівень } \\
\text { вву загроз на } \\
\text { ональні інтереси у } \\
\text { ній сфері } \\
=\frac{\boldsymbol{1}}{\boldsymbol{L}} \sum_{n=\mathbf{1}}^{\boldsymbol{L}} \boldsymbol{Y}_{n}\end{array}$ & & & & & & & & & & & \\
\hline Рівен & ь воєнної безпеки & & & & & & & $-\lambda$ & M) & & & \\
\hline
\end{tabular}

Висновки. Творче використання запропонованих підходів під час оцінювання воєнно-політичних відносин України із країнами - сусідами набуває особливої актуальності в контексті подій останнього часу в деяких 3 них. Безумовно зазначені показники не можна вважати такими, що охоплюють весь спектр різноманітних обставин, слухачам треба пояснювати, що існує багато ситуацій, які можуть впливати на розвиток воєнно-політичної та воєнно- 
стратегічної обстановки, воєнна безпека досягається комплексним використанням політичного, воєнного, економічного, науково-технологічного, демографічного, ресурсного, інформаційного, морально-психологічного потенціалів країни.

\section{ЛІТЕРАТУРА}

1. Горбулін В.П. Засади національної безпеки України: підручник / В.П. Горбулін, А.Б.Качинський - К.:інтертехнологія, 2009. - 272 с.

2. Горбулін В.П. Забезпечення оборони та безпеки України: актуальні проблеми i шляхи вирішення, журнал Наука і суспільство, 2019. [Електронний ресурс] /Режим доступу/ http://politics.ellib.org.ua/pages-8324.html

3. Національна безпека України: еволюція проблем внутрішньої політики: Вибрані наукові праці / О.С. Власюк.- К.: НІСД, 2016 - 528 с. $576 \mathrm{c}$.

4. Національна безпека України: навчальний посібник: В.А. Ліпкан. - К.КНТ, 2009. -

5. Г.П. Ситник Глобальна та національна безпека: словник-довідник [Електронний pecypc] /Режим доступу/ http://www.minregion.gov.ua/wp-content/uploads/2017/11/slovnikGPNB.pdf

6. Закон України "Про національну безпеку України" // Відомості Верховної Ради України.-2018. №4 - Ст. 25.

7. Указ Президента України від 02 вересня 2015 року №555/2015. Про рішення Ради національної безпеки і оборони України "Про нову редакцію Воєнної доктрини України"

8. Основи безпеки держави: підручник / Ю.В. Пунда, В.П. Грищенко, П.М. Грицай та інші - K.: NDUU named after Ivan Cherniakhovskyi, 2017. - 204c.

9. С.І.Ожегов Словник [Електронний ресурс] /Режим доступу/ http://gufo.me/dict/ozhegov

10. Рекомендації з оборонного планування на основі спроможностей у Міністерстві оборони України та Збройних Силах України.12.06.2017 року

\section{LITERATURE}

1. Gorbulin V.P. Principles of national security of Ukraine: textbook / V.P. Gorbulin, AB Kaczynski - K .: intertechnology, 2009. - 272 p.

2. Gorbulin V.P. Ensuring the defense and security of Ukraine: current issues and solutions, Journal Science and Society, 2019. [Electronic resource] / Access mode / http://politics.ellib.org.ua/pages-8324.html

3. National security of Ukraine: the evolution of problems of domestic policy: Selected scientific works / O.S. Vlasyuk.- K .: NISR, $2016-528$ p.

4. National Security of Ukraine: textbook: V.A. Lipkan. - K.KNT, 2009. - 576 c.

5. G.P. Sytnyk Global and national security: dictionary-reference book [Electronic resource] / Access mode / http://www.minregion.gov.ua/wp-content/uploads/2017/11/slovnikGPNB.pdf

6. Law of Ukraine "On National Security of Ukraine" // Bulletin of the Verkhovna Rada of Ukraine. - 2018. №4 - Art. 25.

7. Decree of the President of Ukraine of September 2, 2015 №555 / 2015. On the decision of the National Security and Defense Council of Ukraine "On the new version of the Military Doctrine of Ukraine"

8. Fundamentals of state security: a textbook / Yu.V. Punda, V.P. Gryshcheko, P.M. Gritsay and others - K .: NDUU named after Ivan Cherniakhovskyi, 2017. - 204p.

9. S.I. Ozhegov Dictionary [Electronic resource] / Access mode / http://gufo.me/dict/ozhegov

10. Recommendations for defense planning based on ability in the Ministry of Defense of Ukraine and the Armed Forces of Ukraine. 12.06.2017 


\section{РЕЗЮМЕ}

Павел Минеев,

Национальный университет обороны Украины имени Ивана Черняховского

\section{Рекомендации относительно изложения методики определения уровня военной безопасности}

В ходе выполнения целевой установки учебной дисциплины “Основы военной безопасности государства”, относительно формирования у слушателей оперативнотактического уровня обучения практических навыков и умений, необходимых в ходе подготовки и проведения мероприятий по обеспечению безопасности государства, преподаватели кафедры стратегии национальной безопасности и обороны неоднократно отмечали определенные затруднения в усвоении учебного материала.

В статье исследованы факторы, влияющие на трудности, обозначены научные рекомендации относительно усовершенствования изложения методики определения уровня военной безопасности.

Предлагается четкое определение разницы между формулировками: “военная опасность” и “военная угроза”, влияние наращивания военного потенциала некоторых государств на реализаџию их агрессивных намерений в отномении соседних стран.

Используя показатели, изложенные в статье слушатели за несколько учебных часов могут научиться рассчитывать уровень военной безопасности и соответственно предлагать меры по его повышению.

В качестве показателей определений: “военная угроза” и “военная опасность” со сторонь любого государства учитывать не только намерения и действия его политического руководства относительно возможности применения военной силь, но $и$ боевой потенциал этой страны.

Творческое использование предлагаемых подходов при оценивании военнополитических отнотений Украины с конкретными странами, особенно с соседними приобретает особую актуальность в контексте событий последнего времени в некоторых из них.

Ключевые слова: военная безопасность, уровень военной безопасности, военная опасность, военная угроза.

\section{SUMMARY}

Pavlo Mineev,

National Defence University of Ukraine named after Ivan Cherniakhovskyi

\section{Recommendations regarding the presentation of the methodology for determining the level of military security}

Introduction. Lecturers of the Department of National Security and Defense Strategy have repeatedly noted certain difficulties among students of operational and tactical level of training during classes on the formation of practical skills and abilities necessary for the preparation and implementation of measures to ensure the security of the state.

Purpose. The article investigates the factors influencing the difficulties, outlines scientific recommendations for improving the presentation of the methodology for determining the level of military security.

Methods. Offered clear definition of the difference between the formulations: "military danger" and "military threat" is proposed, account the influence of the military potential of some states on the implementation of their aggressive intentions towards neighboring countries. 
Results. Using the indicators outlined in the article, students can learn to calculate the level of military security in a few academic hours and, accordingly, propose measures to improve it.

Originality. As indexes of definitions: "military threat" and "military danger" from any state, take into account not only the intentions and actions of its political leadership regarding the possibility of using military strenght, but also the combat potential of this country.

Conclusion. The creative use of the proposed approaches in evaluation the militarypolitical relations of Ukraine with specific countries, especially with neighboring countries, becomes especially relevant in the context of recent events in some of them.

Key words: military security, level of military security, military danger, military threat. 